\title{
$=6$
}

\section{๑๑@ Fernando de Azevedo: um sujeito do afeto}

\author{
Raquel Discini de Campos* \\ Norma Discini ${ }^{* *}$
}

\begin{abstract}
Resumo: O presente artigo analisa a crônica A graça do amor e da fé (sobre um manuscrito de minha mãe), publicada pelo intelectual Fernando de Azevedo no jornal $O$ Estado de S. Paulo, no ano de 1955. A crônica diz respeito à vida e à morte de Sara Lemos Almeida de Azevedo. A partir da análise crítica desse escrito, e à luz da Retórica, de Aristóteles, discutimos o ethos de um filho amoroso e grato (cujo discurso é articulado pela visada de um “observador sensível”), bem como o ethos do intelectual da educação, que problematiza práticas relacionadas ao campo educacional (cujo discurso é articulado pela visada de um "observador social" imprimida no relato feito sobre as ações pedagógicas da própria mãe). Assim, se fundam nessa crônica os papéis sociais e os individuais desse sujeito: papéis concomitantes e entrecruzados na constituição do corpo discursivo da crônica.
\end{abstract}

Palavras-chave: Fernando de Azevedo. Ethos. Intelectual da educação. Afeto e efeito de sentido.

\section{Fernando de Azevedo: a subject of affection}

\begin{abstract}
The present paper analyses the chronicle The grace of love and faith (about a manuscript of my mother), published by the intellectual Fernando de Azevedo in the newspaper O Estado de S. Paulo in 1955. The chronicle deals with the life and death of Sarah Lemos de Almeida de Azevedo. From the critical analysis of such chronicle, in the light of Aristotle's Rhetoric, we discuss the ethos of a loving and grateful son (whose discourse is articulated through the view of a

\footnotetext{
${ }^{*}$ Doutora em Educação pela Universidade Estadual Paulista (Unesp-Araraquara). Professora da Faculdade de Educação da Universidade Federal de Uberlândia (UFU). E-mail: raqueldiscini@uol.com.br ORCID: https://orcid.org/0000-0001-5031-3054

** Doutora em Linguística pela Universidade de São Paulo (USP-SP). Professora do Departamento de Linguística da Faculdade de Filosofia, Letras e Ciências Humanas da USPSP. E-mail: normade@uol.com.br ORCID: https://orcid.org/0000-0002-3491-1203
} 
sensitive observer), as well as the ethos of an intellectual of education who problematizes practices related to the educational field (whose discourse is articulated through the view of a "social observer", imprinted in the report of his own mother's pedagogical actions). Thus, the social and individual roles of this subject are fused in this chronicle: concurrent and intercrossed roles in the constitution of the chronicle's discursive body.

Keywords: Fernando de Azevedo. Ethos. Intellectual of education. Affection and sense effect.

\section{Fernando de Azevedo, un homme d'affection}

Résumé: Cet article analise le récit La grâce de l'amour et de la foi (sur un manuscrit de ma mère), publiée par Fernando de Azevedo dans le journal O Estado de S.Paulo en 1955, qui raconte sur la vie et mort de Sara Lemos Almeida de Azevedo. À partir de l'analyse critique de ce récit, et à la lumière de la Rhetorique d'Aristote, on discute l'ethos d'un fils amoureux et reconnaissant (dont le discours est articulé par une vision d'un observateur sensible et penible), ainsi que l'ethos d'un intellectuel de l'éducation, qui problematise les pratiques liées au domaine de l'éducation (dont le discours est articulé par une vision d'un observateur social, imprimé dans le rapport sur les actions pedagogiques de sa mère). Alors, dans ce récit, se mêlent les rôles sociaux et individuels de ce sujet: rôles concomitants et entrecroisés dans la constituition du corps discursif du récit.

Mots-clés: Fernando de Azevedo. Ethos. Intellectuel de l'éducation. Affection et effet de sens.

\section{Notas introdutórias: Imagem pública em temperatura amena (1968)}

Numa segunda-feira, 2 de julho de 1968, o jornal Diário de São Paulo, importante matutino paulista pertencente ao conglomerado midiático Diários Associados, de Assis Chateaubriand, à época um dos 
mais lidos da capital, publicava em sua primeira página, como de praxe, manchetes cotidianas diversas. Falava-se sobre a vitória de Charles de Gaulle nas eleições francesas ("O presidente Charles de Gaulle acaba de obter a vitória eleitoral mais esmagadora da história da Quinta República Francesa); discorria-se a respeito do cotidiano dos políticos no Congresso Nacional ("Brasília. Congresso reinstala trabalhos") e sobre a proposta do ministro Delfim Neto para extinção das cátedras nas universidades brasileiras ("O ministro Delfim Neto, em entrevista exclusiva à EDIÇÃO NACIONAL - DN, domingo pela manhã, esclareceu a proposta de reforma da Universidade brasileira que fez, na semana passada, ao presidente da República”).

Além dessas manchetes, a primeira página do Diário trazia em destaque fotografia de Fernando de Azevedo, com chamada para leitura da série de entrevistas que a partir de então o impresso publicaria a respeito do que nomeava como "crise estudantil e suas perspectivas". O jornal informava: "[...] abre o debate o prof. Fernando de Azevedo, eminente mestre de tantas gerações e um autêntico reformador da educação em nosso país (4.a página)".

Acima da foto de Azevedo e ao lado do cabeçalho, desponta a previsão do tempo nas cidades de São Paulo e Santos, então um dos destinos preferidos dos paulistanos para banhos de mar ("tempo bom, com nevoeiro pela manhã”). Entre a indicação da meteorologia amena e o contexto sócio-histórico em ebulição (ano de 1968) tornam-se implícitos contrastes que remetem ao impacto de nossa percepção: apesar da "temperatura amena", há, no horizonte, o que iria estourar alguns meses após aquele julho de 1968. No dia 13 de dezembro o AI5 seria decretado.

Examinada a seguir, tal página foi assinalada e guardada com esmero pelo próprio Azevedo em seu rico arquivo pessoal - organizado por ele mesmo em vida, e contemporaneamente preservado sob a guarda do IEB-USP. A partir de tais fontes, deparamo-nos com essa figura proeminente da vida cultural do Brasil. Condizente tanto com a trajetória 
biografada do professor, quanto com a simbologia que permeia a presença do intelectual entre seus pares, entre seus leitores e entre aqueles com quem se emparelhou nas lides concernentes à pesquisa atrelada à ação transformadora da ordem da "coisa pública" fica enfatizada a individualidade do reformador da educação brasileira. Entre as páginas impregnadas pela "pátina do tempo", e em especial na quarta página referida, cria corpo discursivo "o autêntico reformador da educação" pública brasileira, cotejado com outros modos de sua presença na vida da coletividade em que ele interfere. Surge então do enunciado jornalístico a representação de Azevedo como: o administrador; o técnico; o especialista em educação; o sociólogo e, por fim, o ensaísta.

O jornal perpetua o percurso biografado do intelectual. Das notas feitas pelo jornalista, sobressai aquele que foi um dos fundadores da Universidade de São Paulo, da qual se tornou catedrático. Paralelamente, é notificado o professor que se distingue como o criador e editor da Biblioteca Pedagógica Brasileira. Subjacente a tais frentes de participação social elencadas, fica enfatizada a presença do pioneiro das causas educacionais, dentre as quais toma lugar a escolanovista. Ao fim e ao cabo, "entre práticas e representações" conforme expressão de Chartier (1988), tão cara aos historiadores da cultura, deparamo-nos naquela quarta página com a arquitetura discursiva que corrobora Azevedo como um dos mais relevantes pensadores do País: como sabemos, não apenas um homem de ideias, mas um homem de ação (CARVALHO, 1989; 2012; PILETTI, 1994, XAVIER, 1998).

Dos registros feitos pelo jornalista, Azevedo emerge de modo especial como autoridade ética: um sujeito potente, cuja "aura" lembraria a dos grandes filósofos. A partir da situação relatada, alusiva à entrevista dada por Azevedo, o jornal cria analogias entre a performance de Azevedo, como o sujeito que dá entrevista, e a atuação de Aristóteles nos diálogos peripatéticos entabulados entre o filósofo e seus discípulos. Tal qual o sábio de Estagira, famoso por caminhar ao ar livre enquanto lia e conversava com os membros de seu círculo, Azevedo, segundo o relato 
jornalístico, pisava firme no assoalho de sua biblioteca, na medida em que refletia sobre o que dizer. Enquanto isso, procurava esclarecer seu interlocutor sobre os fatos relativos ao grande tema de sua vida: a educação. Conforme o relato do jornalista:

$\mathrm{Na}$ casa austera da rua Bragança, entre livros e obras de arte, o professor Fernando de Azevedo caminha pela sala de estudos. É quase uma aula peripatética. E vai dialogando com o jornalista sobre alguns aspectos da problemática estudantil, lucido e culto, corajoso e consequente como nos idos de 1926, quando surpreendeu a educação numa encruzilhada dramática e rasgou a perspectiva de reformas radicais que León Walther, professor do Instituto J.J. Rousseau não vacilou em classificar de verdadeira revolução. Os cabelos alvos como flocos de algodão, a voz firme como nos tempos da militância pedagógica, na Faculdade de Filosofia, o paletó esporte acrescentando um tom ainda mais jovial à mocidade do espírito - os passos de Fernando de Azevedo ressoam na sala enquanto ele enuncia pensamentos, compõe conceitos, reitera ideias e idéias que formaram a sua concepção filosófica, o seu modo compreensivo de encarar o mundo em mudança. ${ }^{1}$

A figura do professor, enquanto é construída pelo jornalista no interior do relato, fica atrelada à gradação crescente do impacto provocado. Para isso, desempenham função própria o uso sequencial de atributos dignificantes (lúcido e culto, corajoso e consequente) e a descrição do vestuário, apresentado mediante a competência de acrescentar características joviais ao espírito do mestre - em ordem de intensidade aumentada. A prosa evolui então com ares majestáticos, ao expressar a majestade do sujeito referido.

\footnotetext{
${ }^{1}$ Leon Walther é autor de Tecno-psicologia do trabalho industrial, livro traduzido por Lourenço Filho e publicado no Brasil em 1929. Walther ministrou cursos em Belo Horizonte e São Paulo em 1927. Sua obra é uma das precursoras da temática da racionalização do trabalho no Brasil (Gonçalves, P. C. Revista Pro-Posições, v. 1, n. 5, 2000).
} 
Não à toa "os passos de Fernando de Azevedo" abrem o segmento final do excerto, em que se encadeiam orações justapostas ("compõe conceitos, reitera ideias"), as quais fazem estender-se de modo labiríntico a duração daquele registro. Fernando de Azevedo, o "ele" referido pelo jornal, vai tomando corpo quase poético - paradoxalmente no interior do campo das atividades jornalísticas - para o que contribuem outros recursos como o uso da comparação: "cabelos alvos como flocos de algodão". Se fica aí esboçado um traço de velhice, ao lado de algum traço de vulnerabilidade que esse ciclo da vida contém na semântica dos discursos, reaparece o viés poético da observação, para aumentar a força da presença evocada como quem não perdeu "voz firme" dos "tempos da militância pedagógica".

Nessa espécie de perfil de Azevedo, esboçado em meio às perguntas subentendidas, presumem-se os temas incorporados pelo entrevistado ao longo de toda sua vida acadêmica: defesa da ciência, da técnica e do planejamento racional na solução das questões educacionais brasileiras, em todos os níveis de ensino; identificação das disparidades regionais do país como um dos grandes problemas da nação; reconhecimento da importância da formação adequada - técnica e científica - de professores para a melhoria qualitativa e quantitativa do ensino; responsabilização do estado brasileiro quanto à situação precária da educação nacional; identificação do desinteresse político estrutural na resolução das questões referentes aos assuntos educacionais.

Da voz jornalística que esboça a figura de Fernando de Azevedo, saltamos para a fala do próprio intelectual, ainda nessa mesma página e mesma edição do jornal. Do discurso de nosso pensador despontam então as perturbações e os tumultos que ocupam, nos idos de 1968, a esfera das atividades educacionais em nosso País. Em meio à objetividade e à clareza recorrentes em seu falar, Azevedo elenca os problemas que enxerga naquele momento no Brasil: 
Em primeiro lugar, a extensão territorial do País e a falta de comunicações rápidas. Em segundo, a diversidade de níveis e aspectos culturais, econômicos e políticos de uma região para outra. Em terceiro lugar, a multiplicação ou cogumelagem de universidades e faculdades criadas de atropelo, sem qualquer planejamento e sem o cuidado preliminar de instalações adequadas (prédios, laboratórios, bibliotecas etc.) e de seleção de pessoal docente. Em quarto lugar, pela preponderância dos jovens na população do País. E em último lugar, pelo lamentável estado em que governos sucessivos deixaram a educação pública no País, sem resolverem e nem sequer porem em via de solução os seus maiores e mais graves problemas. Falta de planejamento, escassez de recursos para o ensino e para pesquisas de que se queixam, e com razão, as universidades e faculdades, ainda as bem instaladas, que são muito poucas. Os problemas relativos ao ensino e à educação foram se agravando a tal ponto que não vejo, para resolvê-los senão a solução revolucionária. Ou uma solução a longo prazo. Sinceramente.

Mantendo precisos os contornos das coisas ("Em primeiro lugar"; "Em segundo"; "Em terceiro lugar"; "Em quarto lugar"...), a inquietação do pensador não deixa dúvida sobre a precariedade da educação brasileira e, em gradação crescente de intensidade, o diagnóstico evolui sob o efeito de suspense: às frases longas, segue a frase lacônica, no final, feita em tom de desabafo: "Sinceramente". Mediante a concisão frástica, corrobora-se o tom de franqueza com que se encerra o excerto da entrevista. Lado a lado com a voz afeita ao zelo institucional, responsiva aos fatos relativos ao campo da educação brasileira, aparece a voz do sujeito afetivo e, simultaneamente, afetado pelas coisas que acontecem "de atropelo" nesse mesmo campo.

Fato é que não apenas as ideias e ações desse intelectual (não sem controvérsias) se confundem com a própria história da educação nacional, tamanha a força de sua atuação na vida pública do País ao longo de boa 
parte do século XX. Suas próprias interpretações historiográficas a respeito da educação brasileira acabaram por configurar-se como paradigmáticas, tanto balizando os marcos temporais utilizados em pesquisas acadêmicas e manuais didáticos de História da Educação, quanto erigindo determinadas representações ainda hoje muito presentes no campo, conforme demonstrado por Carvalho $(1989 ; 2012)$ e Xavier (1998), dentre outros pesquisadores.

$\mathrm{O}$ quadro de pensamento teórico de Azevedo revela-se em sua plenitude nos seus escritos clássicos. Entretanto, nosso intuito aqui não é olhar diretamente para tais escritos, como o Manifesto dos Pioneiros da Educação Nova (1932) ou A Cultura Brasileira (1943); nem mesmo para a sua farta produção bibliográfica, de onde despontam importantes obras como As Ciências no Brasil (1956); A educação entre dois mundos: problemas, perspectivas e orientações (1958) e Sociologia educacional (1959).

Observaremos no presente artigo uma única crônica escrita por ele, pinçada em meio às dezenas delas, e preservada no já mencionado precioso arquivo do IEB. Dessa crônica, intitulada $A$ graça do amor e da fé (sobre um manuscrito de minha mãe), publicada no jornal $O$ Estado de São Paulo no dia 9 de dezembro de 1955, depreendemos a escrita de um filho amoroso que, transcorridos dezoito anos da morte de sua progenitora, lamenta e pranteia a perda "em praça pública": a página d' $O$ Estado, uma das mais importantes ágoras para intelectuais do quilate de Azevedo.

Lembremos que esse intelectual trabalhou como redator, ensaísta e crítico literário d'O Estado nos anos de 1920, tendo lançado naquelas páginas, em 1926, os seus famosos inquéritos sobre arquitetura colonial e sobre a educação pública paulista (VIDAL, 1994). Ao longo de toda a vida colaborou com o impresso, espécie de tribuna que ocupava com desenvoltura para discorrer sobre variados temas, destacadamente os educacionais (http://www.ieb.usp.br/fernando-de-azevedo). 
A partir da leitura da crônica demonstraremos como, mesmo nesse escrito de tom surpreendentemente hagiográfico, pesaroso e evocativo portanto, um texto de alta densidade de emoção - mantêm-se presentes elementos das causas educacionais que Azevedo defendeu ao longo da vida, particularmente aquelas relativas à educação da primeira infância.

\section{O ethos de Fernando de Azevedo}

Pode contribuir para uma leitura que pretende garimpar a imagem do enunciador, criada no interior dos próprios textos, pensar no produtor do texto conforme um ethos, como previu Aristóteles na Retórica (1991). Nessa obra, o Estagirita elucida os três pilares da "arte de persuadir" - o ethos, o logos e o pathos. Se, com o filósofo grego, o ethos é considerado o caráter do orador, apreendido por determinado auditório (caráter que, conforme apresentado via discurso, faz o auditório crer no próprio orador); se, ainda na Retórica, o pathos é a imagem desse auditório, a ser levada em conta pelo orador, para que o discurso proferido seja suficientemente convincente, resta o logos, que é o discurso, a linguagem, a própria “palavra” enunciada. "É o ethos (caráter) que leva à persuasão, quando o discurso é organizado de tal maneira que o orador inspira confiança", diz o filósofo (I, 1356 $)$, que acrescenta: "No entanto, é preciso que essa confiança seja resultado da força do discurso e não de uma prevenção favorável a respeito do orador". $\mathrm{Na}$ aplicação desses conceitos para a crônica referida, Fernando de Azevedo interessa como ethos; o leitor da crônica corresponde ao pathos; o enunciado - que se articula a um gênero pertencente ao campo jornalístico - é o logos.

Do discurso de Azevedo, emergem as marcas da subjetividade do pensador do campo da educação e da sociologia e, junto a tais marcas estão aquelas relativas ao dizer emotivo, particularmente registradas ao evocar a figura materna. Assim, se constitui a enunciação enunciada no interior dos textos - conforme o ethos de Fernando de Azevedo. É um ethos que diz respeito ao que o cronista parece ser no seu discurso - por 
isso falamos de uma imagem do enunciador, que, construída no interior dos textos e recuperada por nós, leitores (ou "auditório"), ao longo da leitura viabilizada conforme as estratégias do próprio autor faz tomar corpo enunciativo o próprio autor.

A partir daí interrogamos como o menino está no homem e como o sujeito lírico está no educador, enquanto se alinham os papéis do filho amoroso e do intelectual da educação para compor, como determinado ethos, a imagem do enunciador - em especial - da crônica. Apreendemos também a possível convergência entre variações do tom da voz do autor, contemplado como efeito de sentido de identidade, produzido no interior do próprio texto: é o Fernando de Azevedo filho afetuoso e é o Fernando de Azevedo, pesquisador da Educação.

Conforme o modo de enunciar-se no interior de seus próprios textos, o ethos de Fernando de Azevedo se consuma pela junção de dois perfis: ao lado do olhar amoroso concentrado na figura de "indefinível bondade e ternura", mas que "havia conquistado, sem o pressentir tamanha autoridade", há o olhar sobre o papel da educadora. O último, que parece preencher apenas a parte final do texto, como a confirmação dos argumentos que compõem o todo da coluna jornalística, nunca deixou de estar subjacente a toda a progressão da crônica. Fica robustecido, no interior do próprio texto, o lugar ocupado pelo Azevedo educador, enquanto o enunciador delineia as estratégias de persuasão, que instituem o leitor como coprodutor do sentido: o leitor, filtro do universo de sentido veiculado pela crônica participa de um contrato de confiança estabelecido com Azevedo. Mas não apenas isso: em meio à crônica, não apenas entendemos o mundo narrado, mas também sentimos a emoção trazida pela "presença viva" da mãe evocada pelo filho. Então, à revelia das passagens textuais - que trazem à luz a racionalidade operante do intelectual e do crítico, passagens nas quais parece voltar a objetividade interpretativa característica do discurso científico - confirma-se o tom ascendente da voz da emoção. Nesse ir-e-vir firma-se o ritmo que 
compõe o ethos de Fernando de Azevedo e, com ele, evoluímos da confiança para a confidência.

\section{A graça do amor e da fé (sobre um manuscrito de minha mãe)}

Temos à mão uma memorabilia de Sara Lemos Almeida de Azevedo construída pelo filho Fernando na interessante fronteira entre a hagiografia e o "depoimento" ou a "confissão", conforme nomeado pelo autor. Não custa lembrar que Azevedo foi um dos fundadores da sociologia no país - e também um dos grandes leitores de Durkheim, conforme indicou Bontempi (2005). Não à toa saltam à vista, a partir do repertório do leitor (particularmente o leitor pesquisador instalado nesse campo das atividades humanas) os traços do método sociológico de análise dos fatos na dita confissão azevediana. Como vimos, ele anuncia ter esperado transcorrer quase duas décadas da passagem de Sara para atingir a isenção necessária e escrever sobre ela, comme il faut. A busca pelo distanciamento emocional certamente vai ao encontro do trato imprimido nos fenômenos, para que se entenda o funcionamento das sociedades - no campo das ciências humanas.

Segundo o relato, é só a partir da releitura post mortem das cartas trocadas entre eles que o filho se sente confiante para escrever sobre a mãe, buscando, para isso, despir-se de qualquer envolvimento emocional profundo. Compatível com esse movimento persuasivo, está o exercício argumentativo de tentar afastar a suspeição, que poderia pairar em torno da veracidade/objetividade da sua escrita. Bem sabemos que, conforme as regras do método sociológico propugnadas desde o século XIX, para observação crítica de um determinado fato seria necessário manter a dita distância temporal. São estas as palavras de Azevedo:

Deixei passar muito tempo após a morte para, adquirida a necessária objetividade e liberdade de juízo, - lançar no papel estas palavras que são um depoimento e, em certa medida, uma confissão. Pois as 
impressões primeiras eram fortes demais para que me fosse possível fugir ao poder de suas sugestões sentimentais.

Uma linha tênue é traçada entre a análise pretensamente fria (sociológica) dos acontecimentos relacionados à vida de Sara - "me parece já suficiente a perspectiva histórica para evocar essa figura singular" - e a saudade do filho órfão: "passar, não me lembra haver passado um dia sem que o pensamento se tivesse voltado para ela"; [...] "a sua imagem que sempre povoou, - alma invisível e presente, as minhas solidões $[\ldots]$ ”. Na dimensão do olhar do filho órfão, que torna a figura da mãe suficientemente forte para invadir o presente do ato de enunciar a crônica, somos apresentados à "figura santa" e também arrebatados por aquelas vivências filiais de Azevedo, que dilaceram o presente de nossa leitura: "[...] todos a tínhamos e a veneravamos como uma santa por sua pureza, pelo desprendimento das coisas terrenas, por seu espírito de sacrifício, pela sua caridade absoluta, por sua imensa bondade e serena resignação". Para isso, contribui o mecanismo de construção do sentido apoiado na enumeração dos atributos maternos, justapostos em ascendência emocional do significado: santa - por sua pureza, pelo desprendimento das coisas terrenas, por seu espírito de sacrificio, pela sua caridade absoluta, por sua imensa bondade e serena resignação. $\mathrm{O}$ paralelismo, que diz respeito à repetição da preposição por empregada com a mesma função, mobiliza, através da sequência dos próprios termos encadeados, a direção ascendente de emoção.

Eis o filho falando da amada mãe. Eis o sociólogo discorrendo a respeito de um sujeito histórico singular. Eis o hagiógrafo construindo a memória de uma santa: "Poderá parecer suspeito o testemunho de um filho, ainda que em torno da figura de sua mãe haja flutuado uma aureola de sobrenatural e tenha ela morrido em odor de santidade". Cabe aqui indicar que segundo a tradição cristã, o odor de santidade, já destacado anteriormente nestas reflexões como componente de uma sinestesia, apresenta-se ainda conforme outras funções. Tal odor, referido por 
Azevedo, pode emanar de pessoas vivas ou mortas, de relíquias ou lugares santos - de acordo com os princípios e costumes ligados à citada tradição cristã. Considerada de difícil definição, diz-se que a fragrância da santidade lembra aquela própria às rosas.

Sara, a mãe idealizada como portadora do odor da santidade, é ainda apresentada mediante o dom de amor ao próximo e à natureza, bem como em conformidade com a fortaleza da fé - sinais evidentes de um "estado de graça", este que diz respeito à comunhão contínua com o próprio Deus (LE GOFF 2010; 2015; 2017).

Sobre a mãe, Azevedo assevera que "[...] pelo seu próprio físico, por sua maneira de ser, de agir e de falar, já se revelavam de modo tão impressionante a presença da Graça e o seu dom gratuito que bastava aparecer para suscitar em todos uma atitude de reverencia e de recolhimento". Conforme ensinou Le Goff (2015), faz parte do sistema cristão a crença de que os gestos são reveladores de santidade, pois expressam os movimentos do coração e das virtudes interiores dos que se mantém em estado de graça.

Segundo o autor, ao discorrer sobre dois santos icônicos da Igreja Católica, São Luiz (2010) e São Francisco de Assis (2017), gestos e virtudes estão ligados à fé manifesta, à esperança, à caridade, à piedade, à devoção, à misericórdia e humildade, à paciência e à penitência, à pureza de consciência, à honestidade e ao martírio.

Interessante ainda notar que, conforme demonstrado por Certeau (2011) ao analisar a escrita das histórias hagiográficas populares, a individualidade conta menos para esse tipo de narrativa que o personagem. Existem modelos ideais, portanto, aos quais as biografias se encaixam, tudo levando o leitor a crer numa escatologia que, para a glória de Deus, pede o triunfo do santo.

Tais modelos são construídos a partir da recorrência de determinadas passagens nas histórias de vida: a) a origem: nobres de nascença se tornam pobres; ou pobres são transformados em reis, subvertendo a ordem terrena das coisas e descortinando os desígnios 
divinos; b) vocação: há um ethos inicial na vida dos santos que determina a máxima de que tudo é dado na origem da vida do eleito. A biografia do santo é, na verdade, a epifania desta verdade original. A esse respeito o jesuíta é lapidar (2011, p. 297): “o santo é aquele que não perde nada do que recebeu" - o que se subentende a própria graça divina.

Para a compreensão dessa graça no campo religioso, ressaltamos que, conforme os rituais católicos, o batismo é o momento em que o ser humano se torna cristão recebendo a graça de Deus, ou seja, tornando-se membro da comunidade ao aceitar os dogmas da Igreja Católica e os mistérios da fé. Neste primeiro sacramento, o cristão recebe os dons do Espírito Santo: sabedoria, inteligência, conselho, fortaleza, ciência, piedade, temor ${ }^{2}$. Mas não são todos os que receberam o batismo que vivem e morrem em estado de graça (como a idealizada Sara), muito pelo contrário. Apenas alguns passam pela vida sem se afastar desse estado inicial de inocência e comunhão com Deus. A graça, conforme as coerções semânticas do discurso religioso, é tida como fruto da misericórdia divina, bem como da disposição de alguns de estar em permanente eucaristia com o Criador. A mãe de Fernando de Azevedo não se afastou dessa graça, conforme a perspectiva do cronista. Por isso beira o universo dos santos, perenizado no gênero hagiografia.

Certeau demostra que nos discursos hagiográficos há uma articulação entre a ordem do parecer e a ordem do ser. Não basta, portanto, para o sujeito, parecer ser santo, é necessário cultivar, cotidianamente, o exercício da santidade, a constância. Nesse tipo de escrita da história, temos narrativas progressivas que nos falam sobre a vida dos mártires cristãos que vão da ascese aos milagres, que, por sua vez, geram grande visibilidade. Mas Certeau destaca que talvez o dado mais importante é que são narrativas que objetivam ir além dos grandes prodígios como os milagres, mirando, ao fundo, as histórias exemplares

\footnotetext{
${ }^{2}$ Fonte: https://w2.vatican.va/content/vatican/pt.html. Acesso em 21 de janeiro de 2019.
} 
das virtudes comuns, da fidelidade das pequenas coisas que constituiriam, afinal, a santidade genuína.

Em sua humildade, calma, piedade, recato, mansuetude, doçura, sensibilidade e amor à natureza - Sara em muito lembrava São Francisco de Assis, conforme o escrutínio do filho. De nossa parte, pensando em "interdiscurso" como o conjunto de discursos que atravessa o interior de determinado enunciado, fazendo ecoar as vozes de outras obras no íntimo daquela que está sendo construída pouco a pouco, e pensando, nós, que o conceito de "interdiscurso" equivale àquele de "dialogismo", tal como formulado por Bakhtin (1988), podemos afirmar que Sara lembra não apenas São Francisco de Assis, mas também o stárietz Zossima d'Os irmãos Karamázov, de Dostoievski. ${ }^{3}$ Bakhtin (1988, p. 88), ao afirmar que a "orientação dialógica é naturalmente um fenômeno próprio a todo discurso", acrescenta:

Apenas o Adão mítico que chegou com a primeira palavra num mundo virgem, ainda não desacreditado, somente este Adão podia realmente evitar por completo esta mútua orientação dialógica do discurso alheio para o objeto. Para o discurso humano, concreto e histórico, isso não é possível: só em certa medida e convencionalmente é que pode dela se afastar (BAKHTIN, 1988, p. 88).

Na crônica, paralelamente à alusão ao "odor da santidade", Azevedo demonstra que, devido ao fato de Sara sentir sobre si, constantemente, o milagre divino, tinha vida ascética e "parecia caminhar sobre a terra, em

\footnotetext{
${ }^{3}$ Os irmãos Karamázov não são diretamente mencionados por Azevedo, mas o trecho de Dostoievsky recuperado por Azevedo nessa crônica bem poderia ter sido proferido pelo monge santo Zossima, mentor espiritual de Aliocha Karamázov. Ainda sobre a possível influência de "Os irmãos Karamázov" nesta crônica azevediana, destaque-se a famosa passagem em que todos os presentes no monastério russo esperam para que o corpo de Zossima exale o odor de santidade após a morte e, no entanto, o que se sente é o cheiro deletério, o cheiro comum do morto e da putrefação do corpo. A icônica passagem do "cheiro deletério" acaba por fortalecer ainda mais a fé de Aliocha no poder de Deus e no milagre da vida. Com Sara morta se mantém o "odor de rosas".
} 
suas peregrinações benfazejas, ao sol e à chuva, com esse alheamento de si mesma, que acusava na própria alimentação, tão pobre e escassa, que todos se perguntavam como podia sobreviver, alimentando-se de tão pouco!".

A crônica permite que venham à luz suas relações interdiscursivas também com a Legenda Aurea, de Jacopo de Varazze, clássico conjunto de biografias de mártires cristãos reunidas no século XIII. Observamos então que, dentre os traços comuns reveladores de santidade, estão o altruísmo, a vida dedicada à caridade, as privações pessoais cotidianas, a fé inabalável, a ascese, a superação de grandes flagelos e provações pessoais, a presença dos estigmas de Cristo, a não decomposição do corpo após a morte, a presença do odor de santidade e, finalmente, a realização de milagres comprovados pela Igreja. Certeau (2011) indica que as virtudes dos santos permitem combinações variadas nas hagiografias. Algumas vidas apresentam tais combinações rareadas, outras, multiplicadas.

Muitos desses indícios estão presentes na reunião de dados biográficos desta mãe piedosa: sofrimento, abnegação, paciência, dignidade diante dos reveses do destino, sabedoria, sensibilidade, intuições, premonições. A enfermidade mortal de um dos filhos queridos, a doença do marido, a derrocada da fortuna familiar e a consequente vida de grandes privações após a perda do patrimônio na vida adulta são algumas tragédias familiares apontadas por Azevedo como provações de Deus que só apuraram a vocação da mãe, este "ser sobre-humano".

Sofrer, sofreu profundamente e, em certa época, sob o impacto de golpes sucessivos; mas todas essas atribulações que nos reservou o destino, longe de lhe quebrarem o ânimo e de lhe abalarem a fortaleza de suas crenças, somente concorreram para lhe retemperar a fé, fortalecer-lhe a resistência, avivar-lhe a caridade e tornar-lhe mais fervoroso o amor de Deus. Foi no sofrimento que se santificou essa alma [...]. Em toda a minha vida, em que tive contacto com homens de grandes virtudes e mulheres de qualidades 
excepcionais, ninguém me deu impressão mais forte e profunda do que a que dela me ficou, da vida sobrenatural $[\ldots]$. Foram seus princípios cristãos, sua piedade e sua fé (era uma católica praticante e fervorosa) que nela produziram uma virtude que raramente floresce em nossos dias: a paciência infinita [...]. Neles e por eles, na sua comunhão com Deus, é que se apuraram a sua sensibilidade e intuição que lhe permitiam espantosos pressentimentos, avisos premonitórios e mesmo estranhas certezas e revelações (ela falava em "revelações de Deus"), para as quais, tão seguras e exatas, e a prazos tão longos, não se encontra explicação natural.

O cronista, por meio da construção contínua da figura materna, revela-se inclinado a tonificar a estesia, como princípio de conotação sensível da própria palavra. Para isso, contribui a própria figura materna, arquitetada por meio de uma lógica concessiva implícita: "Embora $x, y$ " - a mãe é focalizada como aquela que, apesar de tantos infortúnios, tinha constantemente: a fé retemperada; a resistência fortalecida; a caridade avivada. $\mathrm{O}$ contraste, próprio à relação concessiva, aumenta o impacto da emoção tanto para o próprio autor como para o leitor da crônica diante da figura feminina mostrada como ímpar. Emparelhado a esses mecanismos de construção textual, está o emprego de um léxico erudito, bem como o uso de ordem indireta para os termos da oração - conjunto que faz o texto progredir no vigor de uma prosa quase poética.

Foi no sofrimento que se santificou essa alma. [...] Em toda a minha vida, em que tive contacto com homens de grandes virtudes e mulheres de qualidades excepcionais, ninguém me deu impressão mais forte e profunda do que a que dela me ficou, da vida sobrenatural.

Mas, ao longo do texto de Azevedo, a lógica concessiva ocorre sem excluir a recuperação da inteligibilidade dos fatos sociais. Diante dos recursos da erudição da prosa, a lógica concessiva evolui para a sugestão 
de um encadeamento entre causa e efeito dos fatos apresentados. Toma lugar uma lógica implicativa: a mãe retemperava a fé, não apesar dos infortúnios, mas justamente por meio deles. Os infortúnios acabam por constituir a causa desencadeadora da fé sempre renascida e fortalecida o que, para a doxa, soa um paradoxo, que faz se perderem as evidências das coisas da vida.

Azevedo dá continuidade a essa crônica, apresentando de si um simulacro ou uma representação de um produtor de texto que não só procura fazer o leitor crer nos fatos e eventos relatados nos moldes de um depoimento autobiográfico, mas também o simulacro de um enunciador, que, ao trazer à luz recortes da própria história - da qual desponta soberana e humilde a figura materna - faz o leitor emocionarse com o teor memorialista, quase confessional do relato, pautado pela evocação da infância, da juventude e da idade adulta dispostas não como fases estanques em direção linear.

Interseccionam-se sob o transbordamento de gratidão amorosa diante da figura materna, todas as fases da vida daquele que corajosamente expõe sua humanidade enquanto reverencia essa mulher reiteradamente percebida como "santa". O último excerto é também significativo, na medida em que converge para a análise feita por Certeau (2011, p. 301) quanto ao trabalho de simbolização da vida dos santos empreendido pelos hagiógrafos. Segundo Certeau, nesses trabalhos "as descontinuidades do tempo são esmagadas pela permanência daquilo que é o início, o fim e o fundamento", ou seja, a constância da fé.

Certeau ainda demonstra que, mais importante do que o mapeamento dos lugares onde viveu ou peregrinou o santo - de fato, há a recorrência de relatos que demarcam geograficamente partidas e retornos, idas e vindas dos santos - nas hagiografias interessa destacar a orientação para remeter o leitor a uma relativização de lugares particulares (campo/cidade/deserto). "O sentido é um lugar que não é um lugar”, define Certeau (2011, p. 303), visto que o efeito de sentido requerido é o de além. 
Entendendo que o todo da crônica subjaz a cada uma de suas partes, constatamos que, a partir de cada excerto, firma-se o todo da própria crônica, em que, ao pensamento e à sensibilidade do homem maduro tal qual se apresenta o enunciador - se junta a percepção que, fincada no presente do ato de enunciar, desloca-se para o passado. Assim, toma corpo a lembrança da força e da fragilidade da mãe ao longo dos reveses da vida; ou lembrança da força materna, vinda das próprias fragilidades. Enquanto isso, as primeiras sombras de certa tarde descem sobre uma alameda com paineiras em flor, anunciando tanto o fim do dia quanto a visão celestial de Sara ao piano: mãe, arte e natureza em comunhão santa.

Em menino, embevecia-me ao ouvi-la tocar. De volta, porém, do colégio, em uma de minhas férias, dei por falta do piano, de cuja ausência sem lhe ouvir uma queixa me dava a explicação o ambiente doméstico que se transformara completamente com a perda de nossos bens. Mas já moço, ao ir certa vez repousar na fazenda de criação que pertencia a um tio - irmão caríssimo de minha mãe - reservou-me o destino uma grande surpresa. Em uma linda tarde, quando voltávamos de um passeio, por uma alameda de paineiras em flor, que descia para a fazenda, contornando-o pelo flanco de uma colina, inclinada sobre uma lagoa de patos e marrecos, ouvimos a melodia distante de um piano, tocado por mãos mágicas. Quem podia ser a pessoa sob cujos dedos o velho piano se tornava uma criatura submissa e maleável, que lhe dava tudo o que lhe pedia? (...). Aproximando-nos, sem que fossemos percebidos, foi com emoção que a surpreendemos debruçada sobre o piano do casarão antigo, a interpretar, num prodígio de memória, músicas que executara na mocidade. Ela se julgava só, levantou-se, sobressaltada, como se tivesse alguma coisa de que pedir desculpas. A pobreza, que elegera nossa casa por morada, lhe arrebatara o instrumento predileto, mas não a arte, cujo milagre se renovava, sob a inspiração de Deus, numa hora de paz e recolhimento, em que já caiam, descendo sobre o vale, as primeiras sombras da tarde. 


\section{Uma mãe educadora}

Acontece que, do viés do olhar saudoso lançado sobre o passado, emerge a lembrança viva daquele menino admirado diante do caráter de educadora daquela mulher. Nesse ponto, não como algo vindo de um pretérito acabado, mas como um passado que invade o presente, a experiência do menino aprendiz toma corpo, enquanto a progressão dos relatos avança. Para isso, se, de um lado, o cronista traz à tona a venturosa experiência do menino Fernando, de interagir com a educadora singular, de outro, o homem maduro partilha com o leitor a experiência de acompanhar aquela mulher de compleição franzina, movimentandose com firmeza e garbo na prática de ensinar e orientar outras crianças.

Sara é inteligente, amante das artes, especialmente da música e da literatura; é lúcida, comunicativa, cheia de sensibilidade. Entre tais atributos, destaca-se o da mulher que exerce o papel de professora na informalidade do campo da comunicação familiar. Sara ensinou seus filhos a buscar erudição, conforme o relato de Azevedo. Mas, muito além disso, Sara, como educadora (aliás, também como "santa"), soube ensinar "o outro" a amar natureza, a integrar-se a essa natureza, a observar e a ser a própria natureza. Tal qual um pedagogo iluminado, pensa na formação dos pequenos sabendo respeitar as especificidades de cada um, já antevendo a formação do homem de amanhã (BOTO, 1996).

Impossível não notar de imediato os ecos dos escritos não apenas de Rousseau, tão evidentes na crônica azevediana, mas, também, de parte significativa dos pensadores da educação da modernidade ocidental, particularmente no que concerne àquela reflexão que desvela a importância do contato dos pequenos com um mundo não urbano, contemplativo, supostamente mais genuíno e original, presente em tantas obras e tratados filosóficos/educacionais. Sara desenvolve a educação intelectual de seus filhos, mas, muito antes disso, ela está atenta para a educação dos seus sentidos. 
E que sensibilidade artística, a sua! Toda aberta à vida, à luz, à música, ao sorriso da natureza. A caricia do sol, nos seus tons crepusculares, a suavidade do amanhecer que levanta de seus ninhos os pássaros, o canto das aves, o ruído das chuvas, um recanto de bosque, rumoroso de abelhas e cigarras, a beleza das paisagens, tudo a convidava à pesquisa mística e à contemplação das coisas. Não só vivia intensamente, mas nos fazia entrar nesse mundo em que uma flor que desabrocha, um inseto que investe, debatendo-se contra a vidraça, ou o luar que a atravessa, projetando-se pela penumbra de uma casa, um farrapo de nuvem ou um céu coberto de estrelas reencontram, nas almas sensíveis e vibrantes o seu poder secreto de atração.

Para além da ideia de natureza enquanto representação de um espaço geográfico idílico, apresenta-se na crônica de Azevedo o diagnóstico da bem-sucedida relação educativa entre Sara e os filhos, justamente porque ela, educadora exemplar, soube valorizar outra natureza: aquela que diz respeito à índole humana. Sara comprova-se atenta às particularidades das crianças, e aos dons e talentos cultiváveis na natureza infantil. Respeitou o ritmo livre de crescimento dos rebentos, motivando-os a descobrir a si mesmos e ao mundo ao redor, conforme o testemunho do filho. Segundo Boto (1996), para Rousseau, o educando deve ser compreendido não apenas pelo intelecto, mas, primeiramente, pelos sentimentos, gestos e movimentos do corpo, já que a criança é muito mais emoção do que razão. Sara tem "intuição" pedagógica e, para formar o homem, compreende muito bem a criança que existe antes dele e que terá sua existência prolongada no interior dele - de um modo ou de outro.

De intuição divinatória, sua inteligência que fazia tudo por se ocultar, sem jamais consegui-lo, revelava-se de modo particular no tato e na habilidade com que acompanhava, em cada um dos filhos, de temperamentos tão desiguais, o trabalho lento, obscuro, quase inconsciente, que se produz no fundo de uma alma, para romper de repente numa espécie de erupção 
que nos surpreendia a nós mesmos, mas que ela já esperava. Nada, de fato, podia surpreender a quem aprendera a seguir tão de perto os movimentos da alma da criança e do adolescente e tão subtilmente penetrava os segredos do coração humano.

Lembremos a dinâmica idealmente estabelecida entre pedagogo e aluno explicitada no Emílio (2008), obra em que observamos uma prática pedagógica contínua que aparentemente é libertária, mas que, na realidade, é inteiramente planejada pelo preceptor. Uma aprendizagem que é disfarçadamente guiada pelo adulto, objetivando fazer com que a criança percorra um caminho de autonomia, de descoberta e de responsabilidade diante de si e dos outros; uma prática pautada pela razão, mas também, e principalmente, pelo afeto (BOTO, 1996).

Sara, como presença trazida ao presente da memória, sabe valorizar e compreender afetuosamente as necessidades intrínsecas de cada um de seus interlocutores, respeitando o processo de livre crescimento dos filhos. Mas ela também educa os seus numa "afeição vigilante", sabendo escolher o momento adequado para fazer valer a conformação pedagógica intrínseca a todo e qualquer processo educativo.

Conduzia a educação dos filhos com um extraordinário sentido pedagógico e religioso, que, juntamente com um respeito profundo pela criança, a impelia ao cuidado constante de lhes desenvolver a personalidade na direção de seus dons naturais, em vez de lhes impor um molde rígido e único. Compreendia-os com a adivinhação que dá uma afeição vigilante (não se compreende afinal senão pelo amor) e, sempre pronta a perdoar nossas imperfeições e fraquezas, sabia escolher o momento para advertir e os meios de forçar a porta dos corações.

Nesse excerto, volta à luz o "observador social”, sub-reptício ao "observador sensível" - aquele dissimulado nos arroubos de emoção do cronista. Não seria difícil, a partir dessas linhas recém-reproduzidas, 
tematizar o ideal traçado para a presença de quem educa. Confirmam-se os dois perfis do ethos de Fernando de Azevedo: aquele do filho amoroso e grato (articulado pela visada de um "observador sensível”) e aquele do intelectual que problematiza práticas articuladas ao campo da educação (articulado pela visada de um "observador social"). Assim se fundam os papéis sociais e os individuais, concomitantes e entrecruzados, na constituição do corpo discursivo de Azevedo ${ }^{4}$.

Ambos os perfis do ethos de Fernando de Azevedo fazem emergir o pathos evocado pela coluna jornalística. É um pathos composto não como mera "imagem do auditório": um leitor supostamente concebido como ponto de chegada ou de recepção do conteúdo veiculado. Fernando de Azevedo, o enunciador, institui como parceiro e cúmplice o leitor de seu depoimento autobiográfico, o que faz o contrato de confiança estabelecido entre autor e leitor evoluir no modo de uma confidência. Ao leitor previsto como chave de leitura criada pela própria coluna é construída (ao longo do texto) a competência para não apenas partilhar com o colunista a verdade construída no relato, mas também para ajustarse ao ethos, nos seus dois modos de apresentação ou nos seus dois perfis. Para isso, o enunciador se confirma, de um lado, sob o perfil extremamente carinhoso do menino, do jovem e do adulto, sempre apaixonado pela mãe. De outro lado, fica estabelecido o perfil investigativo do intelectual da educação. É o intelectual que enxerga na mãe princípios pedagógicos radicados num conhecimento sensível do mundo. É o sujeito preocupado em precisar, em meio à memória afetiva que invade sua escrita, os fundamentados educacionais firmados em saberes originários.

Chegará o dia, em que a criança, despertando de um pesadelo, já não veja sua mãe, com ela, para the encher os olhos, e adormecer de novo, tranquila, aquele sorriso

\footnotetext{
${ }^{4}$ Noção de um ethos bipartido em dois perfis, um concernente a um "observador social" e outro, concernente a um "observador sensível", ambos constituintes do ator da enunciação (o próprio enunciador) tomamos de estudos feitos por DISCINI (2015).
} 
que é todo ternura e proteção; em que já não a tenha, para acalentá-la, com suas histórias e cantigas de ninar, em que, na hora incerta, já não encontre o filho o regaço, a cujo calor se lhe refaziam as forças e renovavam as esperanças, ou em que sinta, já doente, que não estará á sua cabeceira, para requintar em cuidados, aquela que lhe conheceu e pensou as primeiras feridas, lhe sentiu os primeiros sobressaltos e lhe acendeu, no obscuro amanhecer, as primeiras estrelas. Mas a sua imagem, por maior que seja a distância em que estivermos da última separação, será sempre tão próxima de nós, - como se ainda nos chamasse pelo nome, - que nos custará sempre admitir já a tenhamos perdido.

\section{Referências}

ARISTOTELES. Rhétorique. Paris: Gallimard, 1991.

BAKHTIN, M. Questões de literatura e de estética. A teoria do romance. São Paulo: Editora Unesp/Hucitec, 1988.

BONTEMPI, B. A presença visível e invisível de Durkheim na historiografia da educação brasileira. In: FARIA FILHO, L. M. (Org.). Pensadores sociais e história da educação. Belo Horizonte: Autêntica, 2005.

BOTO, C. A escola do homem novo. Entre o iluminismo e a revolução francesa. São Paulo: Editora Unesp, 1996.

CARVALHO, M. M. C. O novo, o velho, o perigoso: relendo A Cultura Brasileira. Cadernos de Pesquisa, São Paulo, n. 71, p. 29-35, 1989.

CARVALHO, M. M. C. A configuração da historiografia educacional brasileira. In: FREITAS, M. C. (Org.). Historiografia brasileira em perspectiva. São Paulo: Contexto, 2012.

CERTEAU, M. A escrita da História. Rio de Janeiro: Forense, 2011.

CHARTIER, R. A história cultural entre práticas e representações. Lisboa: Difusão Editora, 1988.

DISCINI, N. Corpo e estilo. São Paulo: Contexto, 2015. 
DOSTOIÉVSKI, F. Os irmãos Karamázov. São Paulo: Ed. 34, 2008.

LE GOFF, J. São Luís. Biografia. Rio de Janeiro: Record, 2010.

LE GOFF, J. O maravilhoso e o quotidiano no ocidente medieval. Lisboa: Edições 70, 2015.

LE GOFF, J. São Francisco de Assis. Rio de Janeiro: Record, 2017. PILETTI, Nelson. Fernando de Azevedo. Estudos Avançados, São Paulo, v. 8, n. 22, p. 181-184, 1994. https://doi.org/10.1590/S010340141994000300016

ROUSSEAU, J.-J. Emílio ou Da Educação. São Paulo: Martins Fontes, 2008.

VIDAL, D. Nacionalismo e tradição na prática discursiva de Fernando de Azevedo. Revista do IEB, São Paulo, v. 37, p. 35-53, 1994. https://doi.org/10.11606/issn.2316-901X.v0i37p35-51

XAVIER, L. N. Retrato de corpo inteiro do Brasil: a cultura brasileira por Fernando de Azevedo. Revista da Faculdade de Educação, São Paulo, v. 24, n. 1, p.74, 1998. https://doi.org/10.1590/S010225551998000100005

Data de registro: 05/04/2019

Data de aceite: 19/06/2019 